\title{
NUTRIENT STATUS AND PLANKTON OF NEARSHORE WATER AREA OF KRONOTSKY GULF IN AUGUST 2015
}

\author{
Ekaterina V. Lepskaya ${ }^{1}$, Fedor V. Kazanskiy ${ }^{1}$, Anna A. Polyakova ${ }^{2}$ \\ ${ }^{1}$ Kronotsky State Nature Biosphere Reserve, Russia \\ ${ }^{2}$ Kamchatka Research Institute for Fishery and Oceanography (KamchatRIFO), Russia \\ e-mail:lepskaya@list.ru
}

Received: 15.08.2016

\begin{abstract}
Firstly we carried out a hydrological and hydrobiological study of the nearshore area, at a depth up to $15 \mathrm{~m}$ of Kronotsky Gulf (Kronotsky Reserve, Kamchatka). We have shown that the washout from rivers influences significantly the hydrochemical status of nearshore areas. This parameter determines the level of organic and mineral forms in the compound of phosphorus and nitrogen pools and the content of iron in sea water. The hydrochemical status (particularly - the content of organic compounds) influences the structure of phytoplankton. Diatoms dominate in the locations with relatively high concentrations of mineral forms of phosphorus and nitrogen. In locations with an increased level of these elements in the contents of organic compounds, heterotrophic dinophytes and rotifers dominate. Lists of species of phyto- and zooplankton and their quantitative assessment are presented.
\end{abstract}

Key words: biogenic status, Kamchatka, Kronotsky Gulf, Kronotsky Reserve, nearshore area, plankton.

The Kronotsky State Biospheric Reserve includes the $4.8 \mathrm{~km}$ long nearshore area of Kronotsky gulf with a depth up to $100 \mathrm{~m}$. During expeditions of the Institute for Oceanology AS USSR in spring 1951-1955, a complex study of Kronotsky gulf was carried out to evaluate its commercial fishing importance. During these expeditions, a bathymetrical map of the gulf was compiled, the bottom configuration (Kanaev, 1959) and bottom sediments (Petelin, 1959) were described, a hydrological characteristic was provided (Gamutilov, 1959). Also, a specific composition of phyto-, zoo- and ichthyoplankton and zoobenthos in the gulf was found in general. Their quantitative assessment and spatial distribution were studied (Semina, 1956, 1959; Lubni-Gertsik, 1959; Ponomareva, 1959; Kuznetsov, 1959; Khrapkova, 1959; Polutov \& Vasiljev, 1959). However, data of those important investigations were obtained more than 60 years ago and - only for a spring season (April - May) and bordered by $>30 \mathrm{~m}$ isobaths, excluding the littoral zone.

Therefore, in 2015 a hydrological and hydrobiological monitoring of the nearshore area of Kronotsky gulf started, carrying out a long-term monitoring of its ecological conditions and revealing natural and anthropogenic factors which influence the biota of coastal shallow water.

Subsequently, on 15-16 August 2015 series of hydrochemical and hydrobiological samples were collected. To determine the nutrient status water samples were collected from the water surface. Then they were fixed with chloroform and were kept at a dark and cool place in order to conduct the posterior laboratory analysis. Phosphate phosphorus $\left(\mathrm{PO}_{4}\right)$, total phosphorus (TP) and nitrogen (TN), mineral forms of nitrogen (ammonium $-\mathrm{NH}_{4}$, nitrites $-\mathrm{NO}_{2}$, nitrates $-\mathrm{NO}_{3}$ ), total iron and dissolved silicon were detected in the water samples, using standard methods (Handbook, 2003). Organic forms of nitrogen (ON) and phosphorus (OP) were calculated by subtraction of mineral components from the total concentration of the proper element. Samples of plankton were collected with an Apshtaine net $(\mathrm{D}=18 \mathrm{~cm}$, nylon stocking with cell size $76 \mu \mathrm{m})$ in the nearshore zone (depth $<20 \mathrm{~m}$ ), in the bottomsurface layer. A description of the samples is presented in Table 1, the location of stations in Fig. 1.

NUTRIENT STATUS. A graphic interpretation of data on nutrients in the surface layer of the nearshore area of Kronotsky gulf is presented in Fig. 2. In miniprofiles of estuaries of the rivers Olga and Kronotskaya, we found that a reduction of the washout influence and a decrease of the concentration of nutrients (including $\mathrm{Fe}$ ) take place in relation to the distance from the river estuary. At these locations $50 \%$ of TP was presented by the organic phosphorus component. Similar results were found for a phosphorus pool at the Kozlova point. On the contrary, $70-80 \%$ of phosphorus was mineral in the rivers Stolbovaya and Tjushevka, and in the outlet to the sea station at the river Olga (Fig. 2A). 


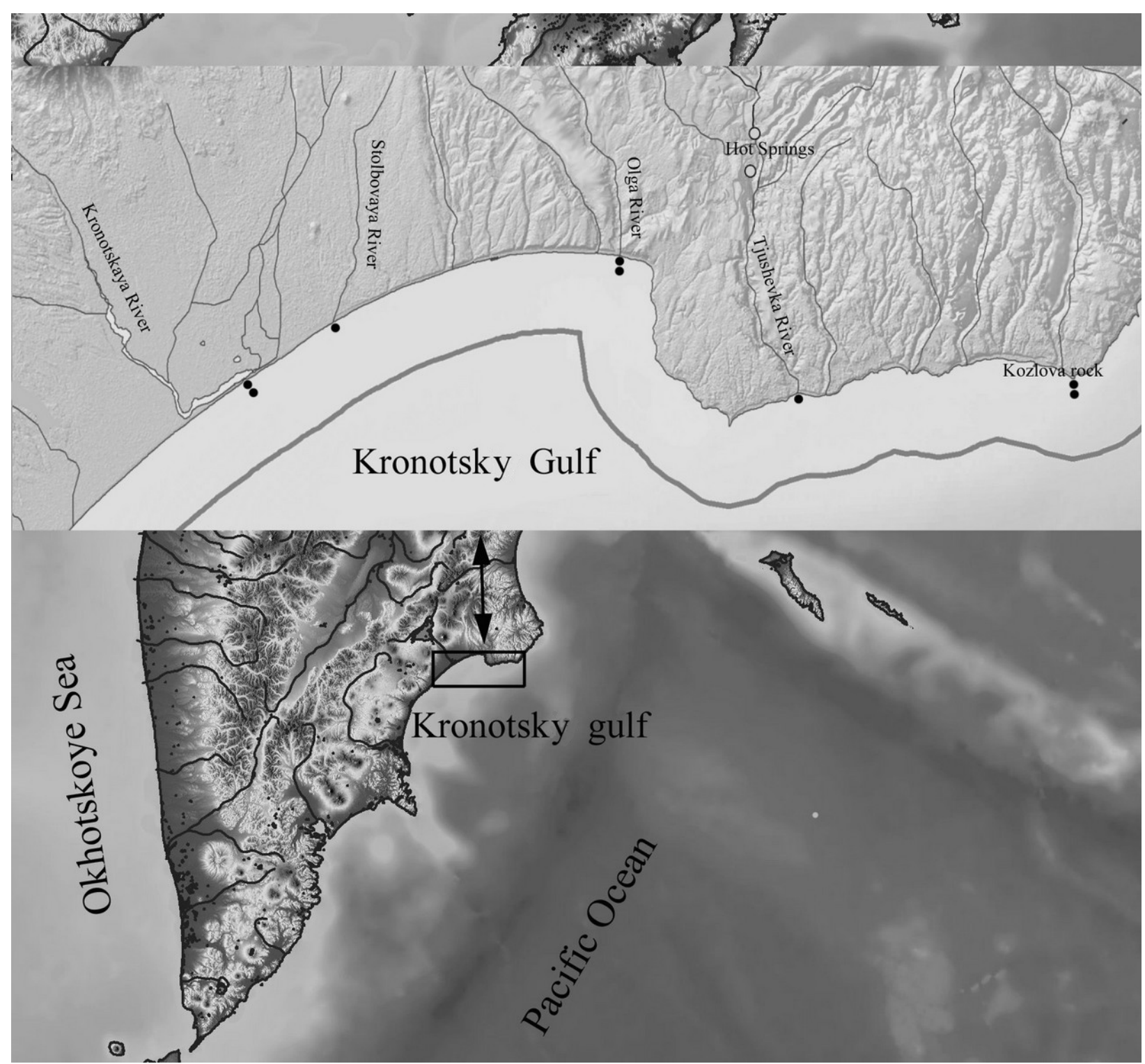

Fig. 1. Schematic map of sampling area in the nearshore area of Kronotsky gulf in August 2015.

Table 1. Description of hydrological and hydrobiologycal samples from Kronotsky gulf on 15-16 August 2015

\begin{tabular}{|c|c|c|c|l|}
\hline № & Longitude & Latitude & Depth (in $\mathrm{m}$ ) & \multicolumn{1}{|c|}{ Comments } \\
\hline 1 & 160.73232 & 54.51852 & 6 & $\begin{array}{l}\text { The Kronotskaya river mouth, 300 m from the shore, just past the } \\
\text { eagre (external edge of cone delta) }\end{array}$ \\
\hline 2 & 160.74021 & 54.51592 & 11 & The Kronotskaya river mouth, $1000 \mathrm{~m}$ from the shore \\
\hline 3 & 160.85414 & 54.55734 & 8 & The Stolbovaya river mouth, $800 \mathrm{~m}$ from the shore \\
\hline 4 & 161.15961 & 54.58396 & 6 & The Olga river mouth, $400 \mathrm{~m}$ from the shore \\
\hline 5 & 161.15779 & 54.58053 & 7.5 & The Olga river mouth, $1000 \mathrm{~m}$ from the shore \\
\hline 6 & 161.37496 & 54.49173 & 9 & $\begin{array}{l}\text { Tjushevka river, 500 } \mathrm{m} \text { from the shore, just past the eagre (external } \\
\text { edge of cone delta) }\end{array}$ \\
\hline 7 & 161.72328 & 54.49107 & 14 & $200 \mathrm{~m}$ from Kozlova point/rock \\
\hline 8 & 161.72410 & 54.49143 & 13 & $500 \mathrm{~m}$ from Kozlova point/rock \\
\hline
\end{tabular}

About $10 \%$ of the nitrogen pool is a sum of mineral forms; the other $90 \%$ is nitrogen as a part of organic compounds. The exceptions are the station in the estuary of the river Stolbovaya and the station at the outlet to the sea in the river Kronotskaya: the concentrations of mineral and organic nitrogen were estimated at $40 \%$ and $30 \%$ respectively (Fig. 2B). From $70 \%$ to $90 \%$ of mineral forms of nitrogen accounted for the reduced ammonium form (Fig. 2C). This is no surprise taking into account the structure of the nitrogen pool with dominating organic compounds. 

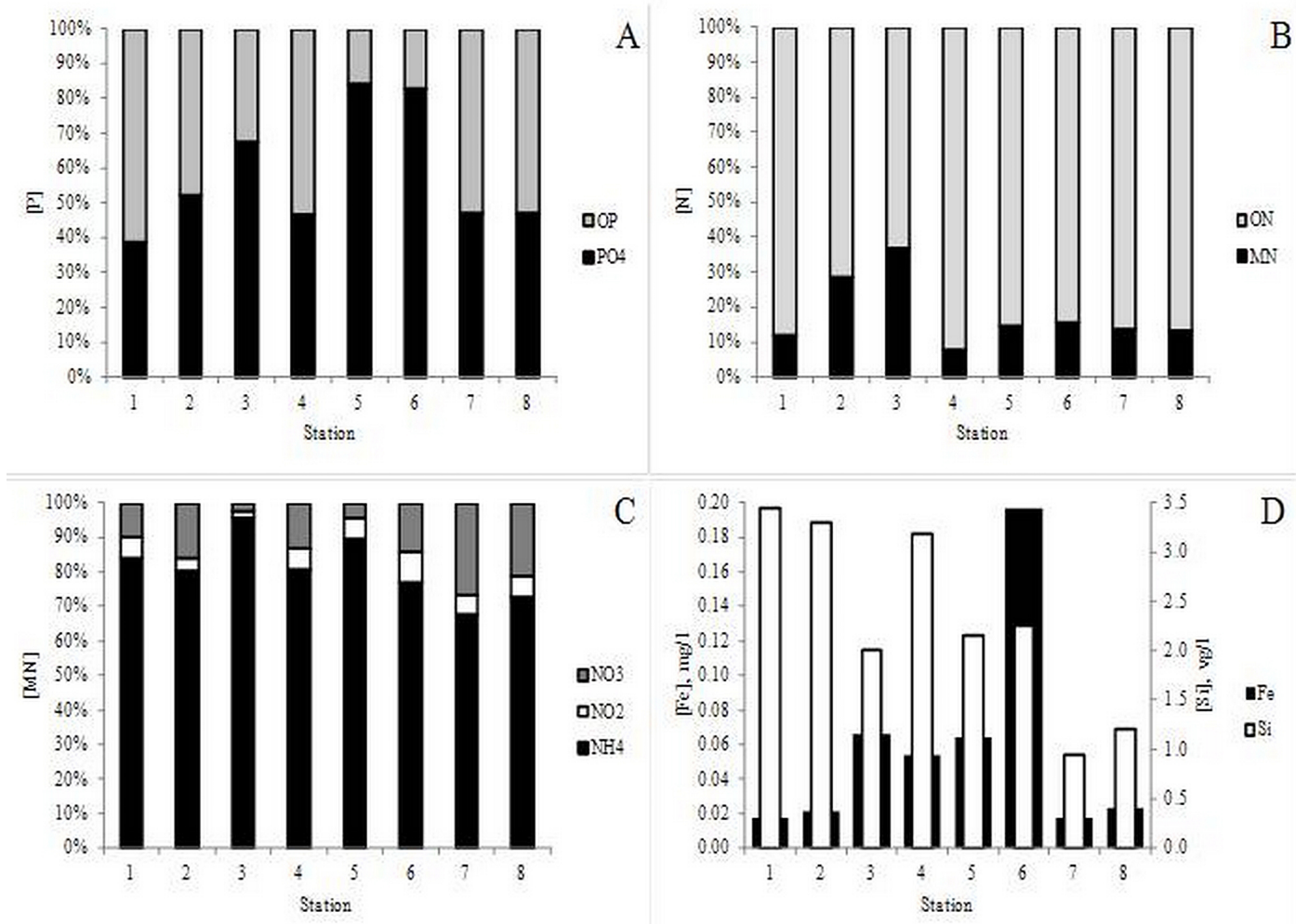

Fig. 2. Nutrient status of nearshore area of Kronotsky Gulf on 15-16 August 2015.

The highest outlet of total iron was found in the river Tjushevka. Perhaps, this is associated with discharging of Tjushevskiye's hot springs to the river. Concentrations of this element were three times less in the rivers Stolbovaya and Olga. The concentration of iron in the zone under influence of the river Kronotskaya and the Kozlova rock was equal to analytic zero $(0.02 \mathrm{mg}$ Fe/l) or little more. Most of the silicon is washed out by the river Kronotskaya (Fig. 2D).

PHYTOPLANKTON. We have registered 62 taxa of microalgae. Diatomic microalgae (Bacillariophyceae) dominate in the species composition (46 species; $74 \%$ of the total number of species). Amongst them, typical marine algae are: Asterionellopsis kariana (Grunow) Round, A. glacialis (Castracane) Round, Cerataulina pelagica (Cleve) Hendey, Chaetoceros affinis Lauder, C. atlanticus Cleve, $C$. concavicornis Mangin, $C$. debilis Cleve, $C$. diadema (Ehrenberg) Gran, C. laciniosus F. Schütt, C. mitra (Bailey) Cleve, C. muelleri Lemmermann, C. simplex Ostenfeld, Eucampia groenlandica Cleve, Fragilariopsis oceanica (Cleve) Hasle, Leptocylindrus danicus Cleve, Nitzschia Hassall sp., Odontella aurita (Lyngbye) Agardh, Proboscia alata (Brightwell) Sundström, Pseudo-nitzschia pungens (Grunow ex Cleve) Hasle, Pseudo-nitzschia seriata (Cleve) H. Peragallo, Rhizosolenia semispina Hensen, R. styliphormis Brightwell, Skeletonema costatum (Greville) Cleve, Thalassionema nitzschioides (Grunow) Mereschkowsky and Thalassiothrix longissima Cleve
\& Grunow. Brackish water species are: Melosira moniliformis (Müller) Agardh and M. varians Agardh. We have also found two freshwater species: Aulacoseira subarctica (O. Müller) Haworth and Lindavia bodanica (Eulenstein \& Grunow) Nakov, Guillory, Julius, Theriot \& Alverson.

There were also found typical marine dinophytes (Dinophyta): Ceratium fusus (Ehrenberg) Dujardin, C. horribum (Cleve) Gran, C. lineatun (Ehrenberg) Cleve, C. longipes (Bailey) Gran, Gymnodinium F. Stein sp., Heterocapsa triquetra (Ehrenberg) F. Stein, Protoperidinium depressum (Bailey) Balech, P. pentagonum (Gran) Balech, Heterocapsa F. Stein sp. Representatives of euglenales (Euglenophya) and green microalgae (Chlorophyta) were sporadic.

Numerically $\left(30,000-100,000\right.$ cells $\left./ \mathrm{m}^{3}\right)$ diatoms also dominated in plankton. These algae were the most abundant in the river Tjushevka estuary where the highest Fe concentration was registered in the water.

The number of dinophytes was two times less. Their highest concentrations were registered in the estuaries of the rivers Olga and Kronotskaya (Fig. 3 ), at stations in the close vicinity of estuaries, at the locations with the highest content of nitrogen and phosphorus in organic compounds.

The structure of the diatomic complex was unique for each station. In the river Tjushevka estuary, where diatoms are the most abundant, the dominating complex was formed by Chaetoceros 
debilis $\left(31,8000\right.$ cells $/ \mathrm{m}^{3}$, so $33 \%$ of the total number) and Pseudo-nitzschia pungens and P. seriata $\left(28,5000\right.$ cells $/ \mathrm{m}^{3}-30 \%$, and 16,2000 cells $/ \mathrm{m}^{3}-$ $17 \%$ respectively). Species dominating in the river Stolbovaya estuary were Leptocylindrus danicus $\left(109,000\right.$ cells $\left./ \mathrm{m}^{3}-33 \%\right)$, Pseudo-nitzschia seriata $\left(70,000\right.$ cells $\left./ \mathrm{m}^{3}-21 \%\right)$, Thalassionema nitzschioides $\left(57,200\right.$ cells $\left./ \mathrm{m}^{3}-17 \%\right)$. At the other stations the found species of diatoms were equally shared, so in equal percentages. The numbers of these species were far below 50,000 cells $/ \mathrm{m}^{3}$ ).

At stations with abundant dinophytes (estuaries of the rivers Kronotskaya and Olga), a dominating complex was formed mainly by species of the genera Ceratium F. Schrank (400-3,600 cells $/ \mathrm{m}^{3}$, and 1,300 cells $/ \mathrm{m}^{3}$ in average) and Gymnodinium (700 4,800 cells $/ \mathrm{m}^{3}$, and 4,100 cells $/ \mathrm{m}^{3}$ in average). In the waters with a low number of dinophytes, representatives of the heterotrophyc genus Protoperidinium R.S. Bergh were the most numerous.

ZOOPLANKTON. Of planktonic organisms, 36 taxa were identified; 21 (58\%) of them were determined at species level. The infusoria Parundella pellucida (Jörgensen, 1899), Ptychocylis urnula (Claparède \& Lachmann, 1858) and foraminifera from the protozoa kingdom (Protista) were found. Multicellular animals were represented by rotifers (Rotatoria): Asplanchna priodonta (Gosse, 1850), Synchaeta bacillifera (Smirnov, 1933); larvae of polychaete worms (Polychaeta), bivalve and gastropod molluscs, lower and higher crustaceans, jellyfish and sea-urchins. Common planktonic crustaceans were various: copepods Acartia longiremis (Lilljeborg, 1853), Eucalanus bungii (Giesbrecht, 1893), Neocalanus plumchrus (Marukawa, 1921), Pseudocalanus minutus (Krøyer, 1845), Microcalanus pygmaeus (Sars, 1900), Oithona similis (Claus, 1866), Tortanus discaudatus ((Thompson \& Scott) in Herdman et al., 1897), Oncaea borealis (Sars, 1918), Metridia pacifica (Brodsky, 1950), Epilabidocera (Wilson, 1932) sp., Ectinosoma neglectum (Sars, 1904), Idyaea furcata (Baird, 1837), Microsetella norvegica (Boeck, 1865), M. rosea (Dana, 1847). Cladocera was represented by one species Evadne nordmanni (Lovèn, 1836); amphipoda - by a group of taxa Gammaridea; mysids Neomysis awatschensis (Brandt, 1851), $N$. mirabilis (Czerniavsky, 1882) and Holmesiella anomala (Ortmann, 1908). In the samples there were also found ostracods (Ostracoda), larvae of balanus and cumaceans, tunicates and jellyfish Fritillaria borealis (Lohmann, 1896), Aglantha digitale (O. Müller, 1776), Obelia longissima (Pallas, 1766).

The contents of nitrogen in the organic matter was the highest in the river Olga outlet. Zooplankton was highly represented in waters at this location. Rotifers dominate there, and copepods are subdominant. Zooplankton was formed by copepods and larvae of sea-urchins in equal shares. Its quantity was three times lower in the river Stolbovaya estuary (Table 2, Fig. 4).

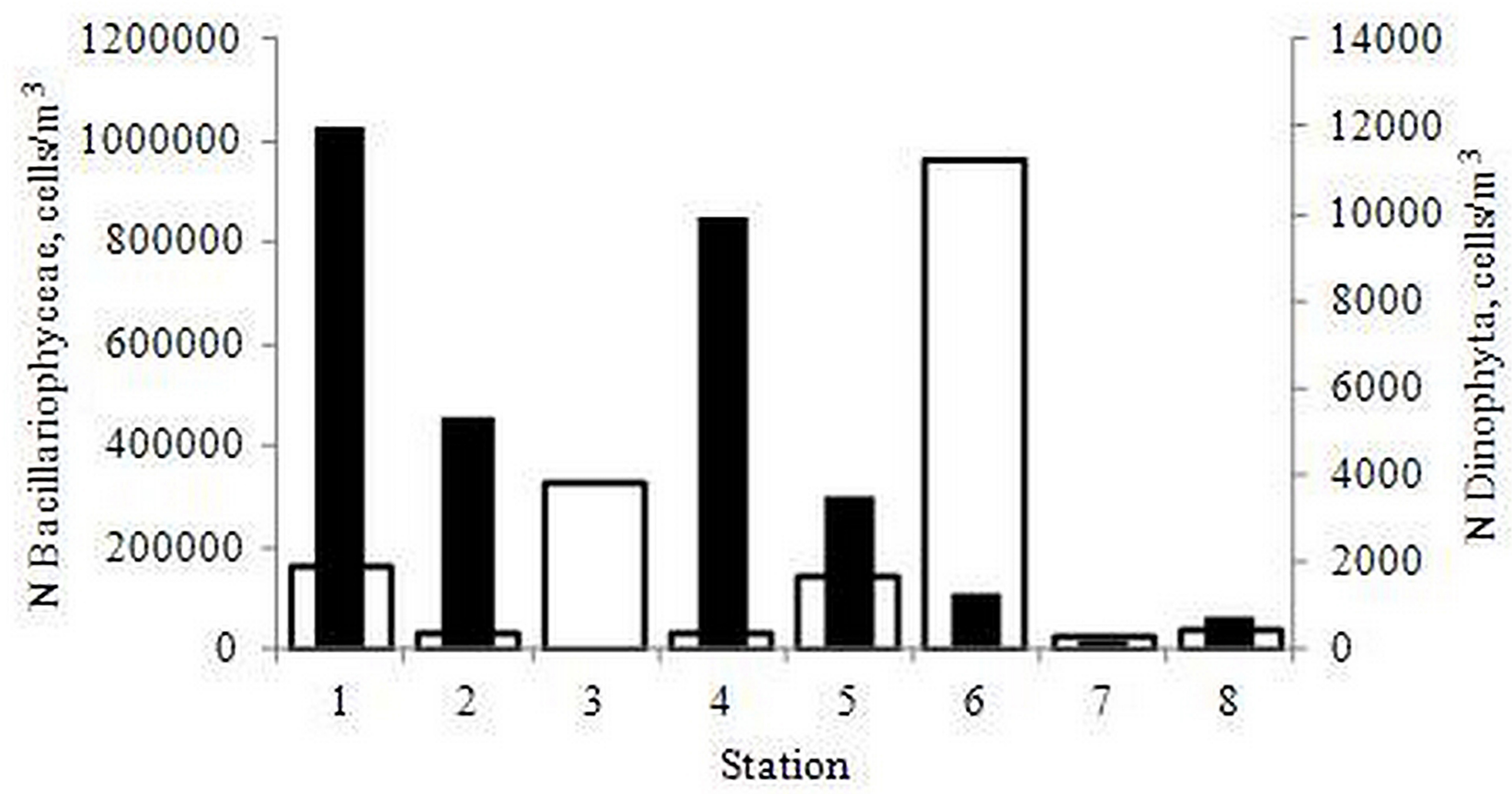

\section{口Bacillariophyceae Dinophyta}

Fig. 3. Number (N) of phytoplankton at nearshore area of Kronotsky Gulf on 15-16 August 2015. 


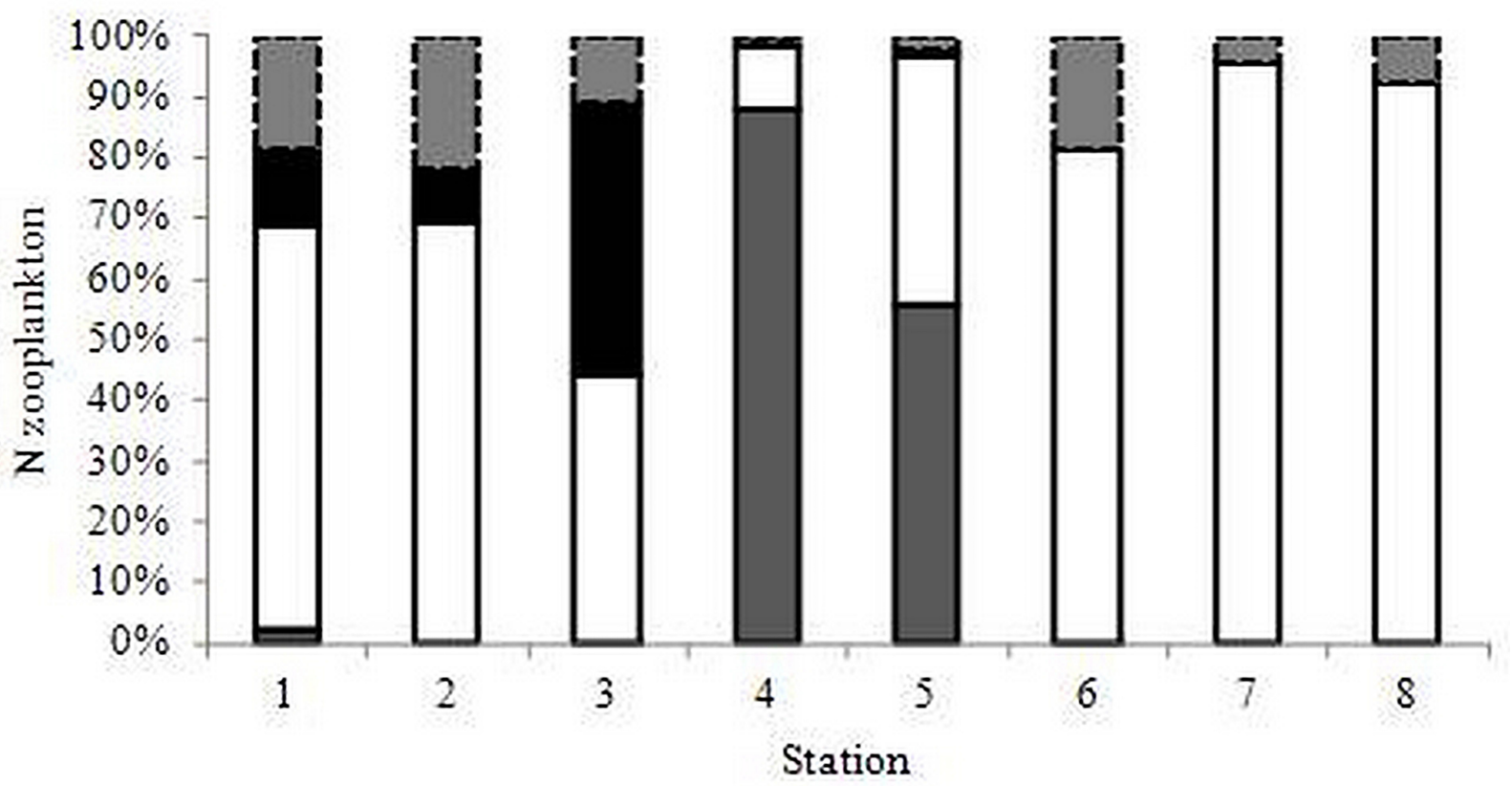

DRotatoria DCopepoda Echinodea GOther

Fig. 4. Structure of zooplankton at the nearshore area of the Kronotsky Gulf on 15-16 August 2015 (Group «Other» includes Cyliata, Foramenifera, Polichaeta, mollusce (Bivalvia, Gastropoda), crustacea (Cladocera, Misidaea, Amphipoda, Ostracoda, Cirripedia, Decapoda), Oicopleura, Medusae).

Table 2. Number (N) of zooplankton at nearshore area of Kronotsky Gulf on 15-16 August 2015

\begin{tabular}{|c|c|c|c|c|c|c|c|c|}
\hline Site & \multicolumn{2}{|c|}{ Kronotskaya river } & Stolbovaya river & \multicolumn{2}{c|}{ Olga river } & Tjushevka river & \multicolumn{2}{c|}{ Kozlov rock } \\
\hline Station & 1 & 2 & 3 & 4 & 5 & 6 & 7 & 8 \\
\hline Number, specimen $/ \mathrm{m}^{3}$ & 5495 & 215 & 14084 & 36915 & 25329 & 2932 & 525 & 1325 \\
\hline
\end{tabular}

Factual material represented above does not allow making unambiguous conclusions on stable patterns of biogenic background, specific composition and plankton diversity, and productivity of separate water areas at the nearshore of Kronotsky gulf. Further investigations within the frameworks of long-term monitoring (successions, regularity, continuity) using standard methods are needed for that.

\section{Acknowledgements}

We thank E.A. Kirillova for translating the paper.

\section{References}

Gamutilov A.E. 1959. Hydrologycal characteristics of water in Kronotsky Gulf. Proceedings of the Institute of Oceanology of the AS USSR 36: 40-58. [In Russian]

Handbook on the chemical analyses in marine and fresh waters for ecological monitoring of commercial fishery water bodies and potential for fishery areas of the oceans. Moscow: VNIRO Press, 2003. 202 p. [In Russian]

Herdman W.A., Thompson I.C., Scott A. 1897. On the Plankton Collected Continuously during Two Traverses of the North Atlantic in the Summer of 1897; with Descriptions of New Species of Copepoda; and an Appendix on Dredging in Puget Sound. Proceedings and Transactions of the Liverpool Biological Society 12: 33.

Khrapkova N.V. 1959. Spawning clusters of commercial fish in Kronotsky Gulf. Proceedings of the Institute of Oceanology of the AS USSR 36: 123-142. [In Russian]

Kanaev V.F. 1959. Relief of the bottom of Kronotsky Gulf. Proceedings of the Institute of Oceanology of the AS USSR 36: 5-20. [In Russian]

Kuznetsov A.I. 1959. Distribution of benthic fauna in Kronotsky Gulf. Proceedings of the Institute of Oceanology of the AS USSR 36: 105-122. [In Russian]

Lubny-Gurtsik E.A. 1959. Distribution of zooplankton in Kronotsky Gulf. Proceedings of the Institute of Oceanology of the AS USSR 36: 92-100. [In Russian]

Petelin V.P. 1959. Bottom sediments of Kronotsky Gulf. Proceedings of the Institute of Oceanology of the AS USSR 36: 21-31. [In Russian] 
Polutov I.A., Vasiljev F.I. 1959. Commercial fish of Kronotsky Gulf and their exploitation. Proceedings of the Institute of Oceanology of the AS USSR 36: 143-157. [In Russian]

Ponomareva L.A. 1959. Euphausiids in Kronotsky Gulf. Proceedings of the Institute of Oceanology of the AS USSR 36: 101-104. [In Russian]
Semina G.I. 1956. Seasonal changes in phytoplankton of western part of the Bering Sea. Botanical Materials of the Department of spore plants of the Botanical Institute of the AS USSR 11: 84-98. [In Russian]

Semina G.I. 1959. Distribution of phytoplankton in Kronotsky Gulf. Proceedings of the Institute of Oceanology of the AS USSR 36: 74-91. [In Russian]

\title{
БИОГЕННЫЙ ФОН И ПЛАНКТОН ПРИБРЕЖНОЙ АКВАТОРИИ КРОНОЦКОГО ЗАЛИВА В АВГУСТЕ 2015 Г.
}

\author{
Е. В. Лепская ${ }^{1}$ Ф. В. Казанский', А. А. Полякова² \\ ${ }^{1}$ Кроноикий государственный природный биосферный заповедник, Россия \\ ${ }^{2}$ Камчатский научно-исследовательский институт рыбного хозяйства и океанографии, Россия \\ e-mail:lepskaya@list.ru
}

\begin{abstract}
Впервые проведено гидролого-гидробиологические обследование прибрежной (глубина не более 15 м) акватории Кроноцкого залива (Кроноцкий заповедник, Камчатка). Показано, что на гидрохимический фон прибрежной акватории значительное влияние оказывает речной вынос, который определяет долю органической и минеральной форм в составе фосфорного и азотного пула, а также содержание железа в морской воде. Гидрохимический фон, в частности содержание органических соединений, влияет на структуру фитопланктона. В точках с относительно высокой концентрацией минеральных форм фосфора и азота доминируют диатомовые водоросли. В акваториях с повышенным содержанием этих элементов в составе органических соединений доминируют гетеротрофные динофитовые водоросли, а среди планктонных животных - коловратки. Приведены списки видов фитопланктона и зоопланктона, а также их количественные оценки.
\end{abstract}

Ключевые слова: биогенный фон, Камчатка, Кроноцкий залив, Кроноцкий заповедник, планктон, прибрежная акватория.. 